(1) We made a special study of muscle, and while in rabbits generally we found equal amounts of muscle iron, in those animals which had been in the Jungfraujoch laboratory we observed a marked decrease in the quantity of the iron. We are of the opinion that during the first months of adaptation, a diminution in exchanges, together with a lowering of the iron content, takes place. This irregularity soon passes off. Clinically speaking, muscular anoxia is expressed in the form of asthenia and disturbances of a painful nature.

(2) : The liver also has occupied our attention to a large extent. In our rabbits, the iron increased. We are of the opinion that this constitutes a first defence reaction against anoxia, the iron playing the part of an active agent of oxidation. Hepatic anoxia is expressed clinically by the characteristic signs of insufficiency of the organ.

(3) The heart very often gives rise to acute symptoms, and in our animals we observed, histologically, traces of sclerosis.

(4) Finally, a number of other organs are also affected, such as the nervous centres or the kidneys; but histologically, in the case of our animals, no lesions were visible.

\section{Conclusions}

In this preliminary study, we have considered the mechanisms of adaptation at an altitude of about 3,500 metres as observed during a sojourn of six months' duration. We have observed the gradual development of a certain number of these mechanisms. The observations which we were able to make on the constitution of the blood have only served to confirm data that had already become classical. On the other hand, the observations which we were able to make on the tissues, lungs, muscle and liver, give rise to a number of new conceptions. For example, in the lung, phenomena of congestion appear which scem to aggravate the anoxæmia, while in the liver and muscles, variations in the iron content seem to be in accordance with adaptation to anoxia.

It remains now to distinguish among the facts which have been observed and described above; those which arise from a successful adaptationthat is to say, from successful acclimatizationand those which in the animal correspond to the chronic mountain sickness manifested in human beings.

In this connexion, non-adaptation to lowering of atmospheric pressure is accompanied by congestion and capillarization of the lungs, by a drop in the oxygen saturation of the blood, by a marked lowering of the total quantity of the carbon dioxide of the blood, by the diminution of the alkaline reserves, by the diminution in muscular iron, and finally, a light sclerosis of the myocardium. On the other hand, the phenomena of effective adaptation give rise to polypnoa, to the unfolding of the alveoli, to emphysema, to increased activity of the hæmatopoietic centres, to an increase in the oxygen capacity of the blood, to the growth of certain buffer systems and finally to an increase of iron in the liver.

Thus our analysis, both chemical and histological, results in arguments in favour of the idea of a complex response of the organism to anoxæmia and of the existence of manifold reactions of acclimatization. It now remains to apply to man the experimental observations which we have carried out on animals. This we hope to be able to do at some future date.

\section{BIUllography}

Piery, M., Enselme, J., Peschlera, C., et Donjon, 1., "Fttude expérimentale de linfluence biologique d'un séjour prolongé à l'altitude. (3): Modificatiuns hé patiques et musculaircs", C.IR. Acad. Sci., 208, 1412 (1939). Piery, M., Eniclme, J., Enselme, Hime. J., et Peschiera, C., "Etude expérimentale de l'influence binlogique d'un séjour prolongé a l'altitude. (1): Les modifications san-
guines", C.R. Acad. Sci., 2.8, 125 (1039).

Piery, M., Martin, J. F., Ensclme, J., et Peschiers, C., "Étude expéri-

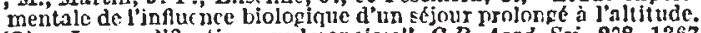
(2) : Les modifications pulmonaires", C.R. Acad. Sci., 208, 1367 (1939).

Piery, MI., Enselme, J., et Peschiera, C., "L'adaptation chimique de (1939).

\title{
NUTRITION DURING WAR-TIME
}

\section{By Sir John Boyd OrR, F.R.S.}

7 HE new science of nutrition has raised issues which profoundly affect the economic and social structure of the State. During the last few years, the agricultural, trade health and social aspects of these issues have been studied by various groups of investigators, and arrangements were made by the Division for the Social and International Relations of Science for a discussion of the subject at the British Association meeting at Dundee on September 8. Owing to the outbreak of war, the discussion did not take place. The results of the investigations promoted by Government committees, research institutes and other organizations in recent years will now prove invaluable to those adjusting the national food supply to war needs.

These studies of the food position have clarified ideas. It is now common knowledge that a great 
deal of disease, ill-health and physical disability, which in the past were regarded as normal and inevitable, are due to faulty diet and, therefore, preventable. We now know the kind of diet needed for health. The British Medical Association standard was calculated to be good enough to prevent obvious clinical signs of malnutrition. According to the results of Sir William Crawford's survey, which agrees closely with the results of other investigations, there are nearly nine million of the population of Great Britain whose diet is below that standard. But there is a great difference be. tween the mere absence of disease and full vigorous health, which is provided for in the higher standard of the League of Nations Nutrition Committee. The dict of nearly half the population does not come up to this higher standard. Quality of diet is correlated with income. Dietary and health surveys have shown that as family income falls the diet becomes worse, and ill-health and poor physique become more prevalent. The infant mortality rate is three times as high among the very poor as among the wealthy. The incidence of discase attributable to faulty diet is several times as high, and the average adult stature is three to four inches less.

In addition to poor diet, there are, of course, other factors associated with poverty, especially bad housing and psychological factors which affect health. It is difficult to assess the relative importance of these, but there is no doubt about their combined effect on health. As the Right Hon. Mr. Bruce has put it : "Poverty is directly correlated with ill-health, disease and premature death."

It used to be assumed that the poor represented an inferior strain of the population and that the high infantile mortality among the poor was Nature's salutary method of eliminating the unfit. This view, which would absolve us from doing anything to abolish poverty, is not supported by facts. Where the infantile mortality rate is highest, the survivors are of poorest physique and vice versa. The factors which make for high infantile mortality seem to be the same factors which make for ill-health and poor physique among the survivors. There is no doubt about the importance of heredity, but we cannot dogmatize about inherited difference in health and physical fitness between the well-to-do and the poor until environmental conditions affecting health and physique are comparable in both classes.

Of these environmental factors, nutrition seems to be of prime importance, because the results of feeding tests show that when the diet of the children of the poorer classes is improved, making it more like that of the well-to-do, the rate of growth of children approaches that of children of the well-to-do classes, and there is a noteworthy improvement in health and physique. In the last twenty-five years, there has been a remarkable im. provement in the national dietary. Consumption of 'protective' foods has increased by nearly fifty per cent; there has been an accompanying improve. ment in national health and physique; infant mortality rate has fallen by nearly fifty per cent; the gross forms of deficiency diseases, such as rickets, are rapidly disappearing; deaths from tuberculosis, resistance to which has increased by good diet, has been reduced by nearly fifty per cent; children leaving school to.day are two to three inches taller than their parents at the same age. What has been done shows how easily life could be saved and life and happiness increased. It affords complete justification for the public health and social services which have made the 'protective' foods, especially milk, available, free or at reduced prices, to necessitous mothers and children.

Although such a remarkable improvement has taken place, we are still far from our goal, which is an adequate diet for every member of the community, however poor. In the United States, the British Dominions and other countries, where investigations have been done, the position is not markedly dissimilar to what it is in Great Britain. National health and physique, especially of the poorer classes, is far below what it would be if the new knowledge of nutrition were fully applied. This opens up a glorious vista for the future. Even in the most advanced countries, man has not yet attained his full capacity for health and physical fitness. We have the knowledge and we can provide the means for a further great advance in human welfare. Rapid improvements have been made in Great Britain and elsewhere, and, in an atmosphere of increasing good will, schemes were maturing for adjusting national food policies to provide diets for the whole community on the standard now known to be necessary for health.

It would be disastrous if this work were pushed into the background as being of minor importance in war-time. As a matter of fact, the nutrition problem becomes even more urgent in war. This will continue to be a war of nerves, and the issue may well depend upon whether or not the people are able to withstand the physical and mental strain of war. Malnutrition, due to lack of 'protective' foods, leads to lack of capacity for sustained physical and mental effort, apathy and despondency, all factors which make for fear and a spirit of defeatism. For maintaining the will to victory in this war for liberty, the quality of the national diet is as important as the quantity. Our aim should be to accelerate the remarkable improrement in diet and accompanying improvement in health of the last few years. 
Fortunately, the food policy for war is the same as the food policy needed for peace, namely, increased production and consumption of "protective' foods. Food defence, in addition to providing stores of wheat, sugar, fats and other foods, and organizing distribution and rationing, must consider the question of what additional foodstuffs agriculture must produce to maintain and improve the national diet. Yield of protein, vitamins and minerals per acre must be considered as well as yield of calories.

This is one of the war measures for which we need not grudge expense. A war food policy, designed to increase the health and vigour of the population and to adjust agriculture and trade in foods to the needs of the population, will leave a national asset which will be invaluable in the reconstruction period after the war for world freedom is won. There is here a great opportunity for the Ministry of Food to co-operate with the Ministries of Health and Agriculture, involving a national policy which will help to win the war and have at the end of it a vigorous race ready to take a lead in post-war world reconstruction.

\section{O B I T UARIES}

Prof. Sigmund Freud, For. Mem. R.S.

$\mathrm{B}^{\mathrm{x}}$ $Y$ the death of Sigmund Freud, the world of psychology has lost its best-known figure. Born in 1856 of Jewish parents in Mroravia, he decided at an early age to take up the study of medicine. While still in the twenties he went to Paris to study psychiatry under Charcot; and at the age of thirty. one returned to Vienna, where he spent the greater part of his life.

To the scientific world, Freud's name first became known through researches on the nervous system. But while working in Trance he became strongly impressed with a notion that had already been taking shapo in his own mind, the notion, namely, that in the existing state of physiological knowledge nervous disorders are best investigated, not by looking for physical causes, but by studying montal causes, particularly emotional conflict and repression. In his early work as a neurologist he began by applying the methods of hypnosis which he had learnt in Paris. Gradually, however, he abandoned this approach for a more effective technique, to which he gave the name of psycho-analysis. The method, suggested it would seem by the work of Wundt and Galton on freo association, threw an unexpected light on symptoms and processes which the patient's answers to the direct questioning of the consultant were apt to leave wholly obscure or even to misinterpret. To-day the term psycho-analysis is applied, not morely to the method, but also to the vast body of doctrino built up with its aid by Freud and his disciples : it might bo loosely defined as the empirical study of unconscious mental processes.

Tho essential framework of Freud's views was laid down in his early writings on hysteria nearly forty years ago. He never hesitated to modify or expand his hypotheses; but in the main his later publications, running to something like two hundred books and articles, consist in suggestive and provocative applications of these leading ideas and principles to various branches of psychology. From the study of major nervous disorders, he proceeded to minor abnormalities that characterize mental life for every one of us-dreams, lapses of memory, slips of the tongue, and the like; and thus showed in concrete detail how the scientific study of the exnggernted reactions of pathological cases may explain the more puzzling or neglected phenomena of normal persons. From this he turned to other fields. Art, poetry, religion, crime, mythology, anthropology-nearly every sphere of life was illuminated by the inquiries ho attempted and the principles that ho applied.

Freud was, indeed, one of the boldest and most original of thinkers. Nevertheless, the isolated items in his theories were by no means so novel as is popularly supposed. Both in Great Britain and in America a strong reaction against the intellectualistic psychologies of the nineteenth century had already set in: James and Stout had emphasized the need for a more dynamic psychology; NoDougall had urged the importance of unconscious motives, particularly in the instinctive and emotional life; Janet had emphasized the importance of dissociation in mental disorder and diseaso; Havolock Ellis had attempted a scientific study both of dreams and of sex. Freud's own great achiovement was porhaps to incorporate what was most fruitful in these ideas in a single, striking, unifying system, and to collect a vast amount of empirical data from a wids variety of sources, all illustrating much the same fundamental mechanisms of the mind.

Though widely read in psychological literatureEnglish and American as well as German and French - Freud nover cared to bring his own viows into line with academic tradition. 'This led at first to wide misunderstanding, but was equally a condition of his fresh and revolutionary outlook. In Great Britain, as elsewhere, his bold speculations and even bolder expression of them aroused initial opposition. But a wide experience of nervous disorders during the Wnr of 1914-18 quickly convinced workers like Rivers, Myers and MrcDougall that there was a most important foundation of truth in the novel doctrines that Freud had advanced. It was perhaps tho very antagonism aroused by his frank utterances that in the end gave a wide publicity to the new attitude towards mental 